\title{
Analysis of Decadal Rainfall and Temperature Trend in Warri, Nigeria
}

\author{
Oyeleke Oluwaseun Oyerinde
}

\section{ABSTRACT}

\begin{abstract}
This study investigates rainfall and temperature trend in Warri, Delta State, Nigeria using data derived from Nigerian Meteorological Agency between 2005 and 2015. Data was analyzed to reveal trend in temperature and rainfall values in the years under study and to determine whether there were significant variations. Analysis of rainfall data shows that 2007 had the lowest total rainfall over the 11 year period with a total annual rainfall of $2030.58 \mathrm{~mm}$ while 2015 was the year with the highest annual rainfall record of $3183.6 \mathrm{~mm}$. The mean monthly Rainfall indicates that January has the lowest record of rainfall with a total of $36.9 \mathrm{~mm}$ while July is the month with highest value of $423.2 \mathrm{~mm}$. Results further indicates that June has the lowest mean monthly temperature over the 11 year period of $20^{\circ} \mathrm{C}$ while March has the highest record of $29.6^{\circ} \mathrm{C}$. Dominant temperature ranges between $26.1^{\circ} \mathrm{C}$ and $26.8^{\circ} \mathrm{C}$ closely followed by $27.7-28.4^{\circ} \mathrm{C}$ which are quite close to the mean monthly values in the area. Analysis of rainfall data confirms an increasing trend.
\end{abstract}

Keywords: Temperature, Rainfall, Trend analysis, Warri.

\author{
Published Online: March 27, 2021 \\ ISSN: $2684-446 \mathrm{X}$ \\ DOI :10.24018/ejgeo.2021.2.2.120 \\ Oyeleke Oluwaseun Oyerinde* \\ Department of Environmental \\ Management and Toxicology, Federal \\ University of Petroleum Resources \\ Effurun, Delta State, Nigeria. \\ (e-mail: oyerinde.oyeleke ${ }^{\circledR}$ fupre.edu.ng)
}

*Corresponding Author

\section{INTRODUCTION}

The evidence of rainfall and temperature trend is recognized by today's world as one of the important environmental problems that affect humanity. Recent changes in climate have led to warmer temperatures, heavy rainfall, drought, and floods etc. Therefore, the knowledge of climate variability over the period of instrumental records and beyond on different temporal and spatial scale is important to understand the nature of different climate systems and their impact on the environment and society [1].

Climate variability is the variations of the normal state and other statistics of the climate on all temporal and spatial scales beyond that of individual weather events. Variability may result from natural internal processes within the climate system (internal variability) or from anthropogenic external forces (external variability) [2]. The global climate has changed rapidly with the global mean temperature increasing by $0.7{ }^{\circ} \mathrm{C}$ within the last century. However, the rates of change are significantly different among regions. This is primarily due to the varied types of land surfaces with different surface albedo, evapotranspiration and carbon cycle affecting the climate in different ways [2].

Temperature and rainfall trend detection is an important exercise that can provide an indication of the magnitude of climate or weather variability providing a clear picture of the impact in the trends of the study area and a prerequisite for developing a framework for mitigation and adaptation policies. The knowledge of temperature and rainfall trends has tremendous potential benefits. First, it brings to limelight the potential effect of climate variability in the area. Second, it enlightens relevant authorities and residents on applicable adaptation measures. Finally, it provides empirical basis for the formulation of effective mitigation policies.

The Niger Delta is a very sensitive area housing several ecosystems or local biomes. This has made it particularly vulnerable to little changes in environmental conditions, weather variability inclusive.

Based on this background, this study attempts to ascertain the degree of variability in rainfall and temperature pattern in Warri, Delta State, Nigeria with a view to uncover the implications of observed trend and variations (if any) and to understand, manage and possibly predict the aforementioned related challenges thereby providing an empirical basis for the formulation of effective adaptation and mitigation policies.

\section{STUdy AREA}

\section{A. Location and Position}

The study area, Warri, has its geographical coordinates as $5^{\circ} 31^{\prime} \mathrm{N} 5^{\circ} 45^{\prime} \mathrm{E} / 5.517^{\circ} \mathrm{N} 5.750^{\circ} \mathrm{E} / 5.517 ; 5.750$. Warri is a city in Delta State, Nigeria. Warri city is one of the major hubs of petroleum activities and businesses in the southern Nigeria. Delta state, southern Nigeria is bounded by Edo state to the north, Anambra state to the east, River's state to the southeast, Bayelsa state to the south, the Bight of Benin of the Atlantic Ocean to the west, and Ondo state to the northwest. On the east and south the state is bounded by the lower course and delta of the Niger River. 


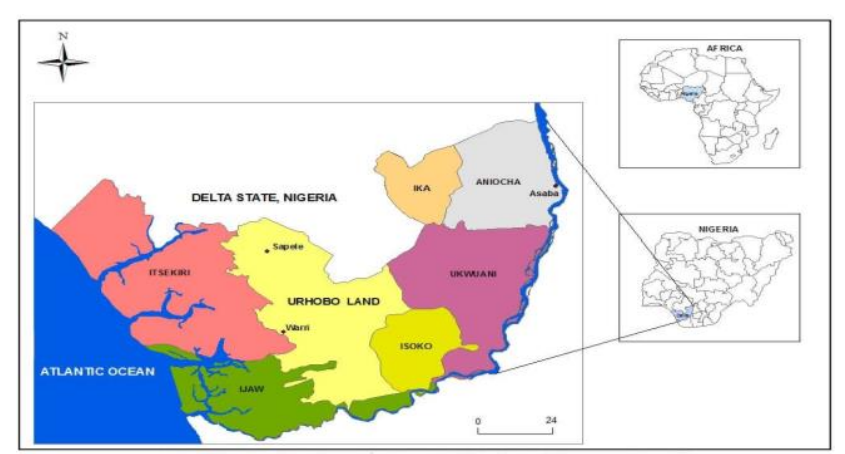

Fig. 1. Map of Delta State Showing Study Area [3].

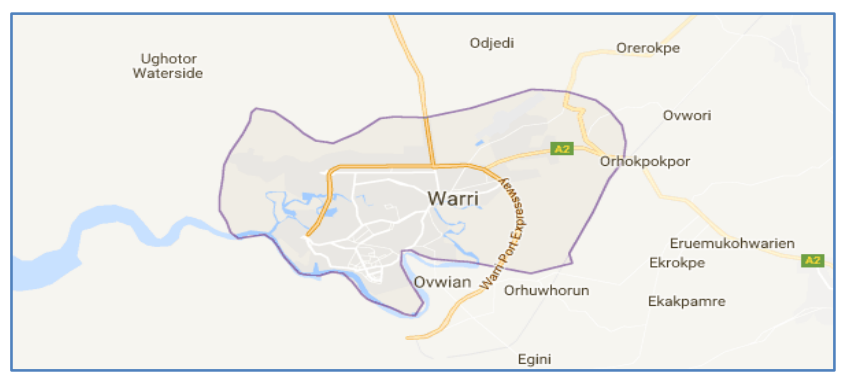

Fig. 2.: Map of Warri.

\section{B. Climate and Vegetation}

The climate is equatorial and is marked by two distinct seasons: the dry season and the rainy season. The dry season lasts from about November to April and is significantly marked by the cool "harmattan" dusty haze from the northeast winds. The rainy season spans May to October with a brief dry spell in August, but it frequently rains even in the dry season. It has mean annual temperature of $32.8{ }^{\circ} \mathrm{C}$ and annual rainfall amount of $2673.8 \mathrm{~mm}$. There are high temperatures of $36^{\circ} \mathrm{C}$ and $37^{\circ} \mathrm{C}$. The natural vegetation is of rainforest with swamp forest in some areas. The forest is rich in timber trees, palm trees, as well as fruit trees [4].

\section{MATERIALS AND METHOD}

Records of Rainfall and Monthly Average Temperature from January 2005 to December 2015 measured at 06 GMT in Nigeria and entered against day preceding in accordance with best practice were obtained from Nigerian Meteorological Agency (NIMET), Warri station, number 0505.34, at an Altitude of $2.44 \mathrm{~m}$.

Descriptive analysis such as the mean monthly rainfall and average monthly temperature was applied together with their range, mode, medium standard deviation coefficients of variation. Line chart method was used to depict the trend and pattern.

\section{Discussion OF RESUlt}

\section{A. Monthly and Annual Total Rainfall}

Fig. 3 shows the trend of total rainfall across the years (2005 to 2015). It is immediately obvious that year 2007 has the recorded minimum total rainfall within the period under consideration while year 2008 has the highest total amount of rainfall change followed by another sharp decline in 2009 while there is gradual rise in the remaining years.
From the trend analysis, peak periods of 2006, 2008, 2012 and 2015 coincides with pronounced flooding events experienced in the city. These periods witnessed high water levels in rivers, ponds, creeks, and widespread flooding within the region. The continuing rise also suggests there are possibilities of the flooding in the nearest future due to increasing rainfall.

During the flood episodes, it was observed that agricultural production levels were lower than what was usually obtained in previous years. In one of the synopses of the flood impact on Agriculture in the region, it was indicated that that the major food crops such as cassava, groundnut, potato and palm oil were all severely affected [5].

Also, as a result of the flooding activities occasioned by the heavy rains, there were lack of clean drinking water and outbreak of cholera within the study region. Other flood associated health problem within the region includes diarrhea, malaria, and typhoid.

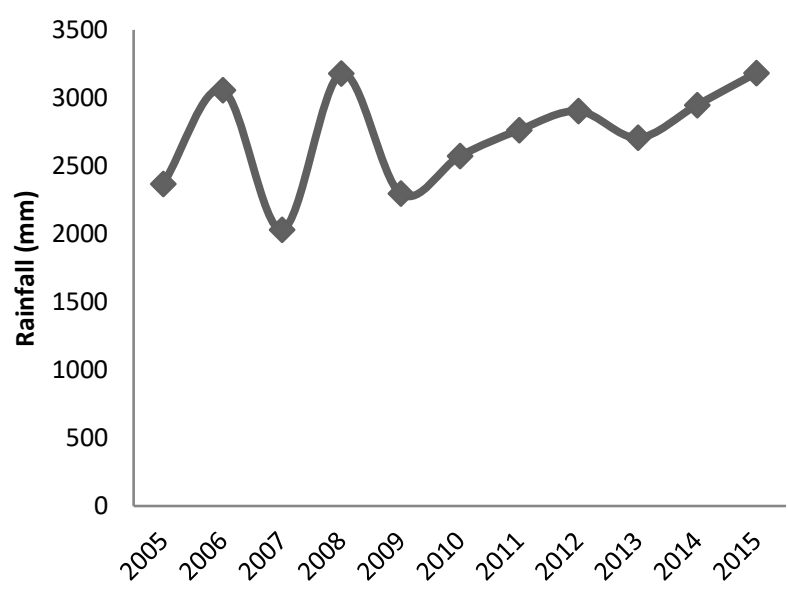

Fig. 3. Annual Rainfall Trend.

Fig. 4 reveals the annual distribution of rainfall in the study area. It shows that rainfall volume recorded gradually rose from January through April and reaches a first peak in July and second peak in September. Thereafter, a sharp decline is experienced between October and November which trails off to December.

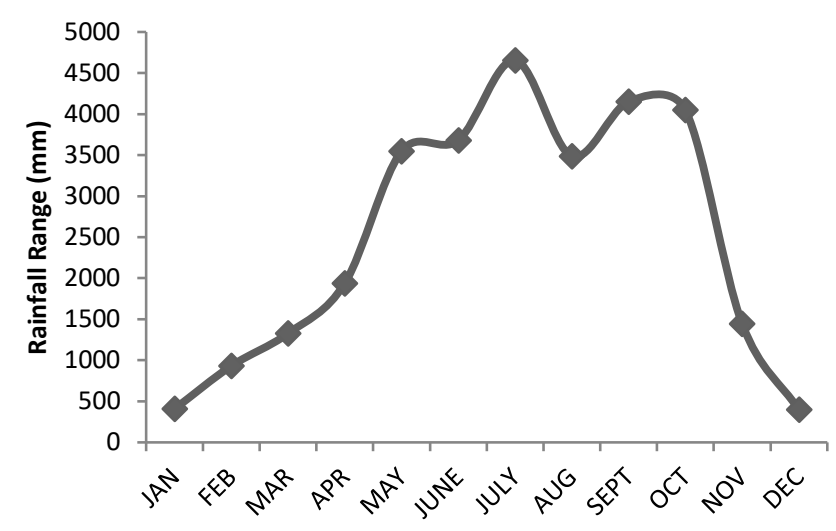

Fig. 4. Monthly Rainfall. 
TABLE I: MONTHLY AND ANNUAL RAINFALL

\begin{tabular}{|c|c|c|c|c|c|c|c|c|c|c|c|c|c|}
\hline \multirow[b]{2}{*}{ YEARS } & \multicolumn{13}{|c|}{ Months } \\
\hline & JAN & FEB & MAR & APR & MAY & JUN & JUL & AUG & SEPT & OCT & NOV & DEC & $\begin{array}{c}\text { Annual } \\
\text { Total }\end{array}$ \\
\hline 2005 & 37.3 & 21.7 & 191.2 & 104.1 & 315.1 & 216.4 & 592.4 & 146.7 & 432.5 & 203.6 & 68.6 & 39.0 & 2368.6 \\
\hline 2006 & 111.0 & 171.9 & 177.6 & 149.2 & 453.9 & 259.4 & 368.4 & 305.6 & 525.3 & 493.2 & 25.0 & 17.7 & 3058.2 \\
\hline 2007 & $\mathrm{TR}$ & 60.3 & 34.5 & 44.4 & 286.6 & 58.18 & 364.2 & 140.2 & 493.9 & 448.9 & 65.9 & 33.5 & 2030.58 \\
\hline 2008 & 20.4 & 10.0 & 172.6 & 337.8 & 295.1 & 467.4 & 501.9 & 635.4 & 428.5 & 214.2 & 72.5 & 23.8 & 3179.6 \\
\hline 2009 & 13.0 & 86.1 & 66.9 & 138.2 & 209.2 & 383.4 & 407.1 & 414.5 & 117.5 & 368.8 & 76.0 & 15.7 & 2296.4 \\
\hline 2010 & 8.2 & 118.4 & 89.5 & 218.9 & 379.8 & 250.1 & 192.4 & 302.4 & 536.6 & 296.4 & 157.7 & 21.8 & 2572.2 \\
\hline 2011 & $\mathrm{TR}$ & 136.4 & 67.0 & 143.0 & 366.6 & 332.5 & 671.6 & 458.2 & 254.8 & 199.1 & 131.0 & 3.7 & 2763.9 \\
\hline 2012 & 20.7 & 174.2 & 46.9 & 130.0 & 358.6 & 470.1 & 678.1 & 133.4 & 313.1 & 339.6 & 166.4 & 72.0 & 2903.1 \\
\hline 2013 & 107.0 & 15.7 & 151.6 & 209.3 & 174.3 & 458.6 & 497.5 & 183.8 & 185.2 & 483.6 & 203.1 & 37.3 & 2707.0 \\
\hline 2014 & 89.3 & 17.9 & 190.0 & 225.5 & 348.0 & 304.9 & 194.2 & 349.4 & 374.9 & 474.9 & 250.7 & 128.2 & 2947.9 \\
\hline 2015 & $\mathrm{TR}$ & 118.4 & 138.5 & 238.1 & 359.6 & 479.1 & 187.5 & 417.5 & 489.0 & 524.1 & 227.4 & 4.4 & 3183.6 \\
\hline $\begin{array}{c}\text { Month } \\
\text { Total }\end{array}$ & 406.9 & 931.0 & 1326.3 & 1938.5 & 3546.8 & 3680.08 & 4655.3 & 3487.1 & 4151.3 & 4046.4 & 1444.3 & 397.1 & 30011.1 \\
\hline
\end{tabular}

\section{B. Mean Monthly and Annual Rainfall}

Fig. 5 shows that the month of July has the highest amount of mean monthly rainfall of $423.2 \mathrm{~mm}$ with Jan and Dec having the lowest amount of Mean Monthly rainfall of 50.9 $\mathrm{mm}$ and $36.1 \mathrm{~mm}$ respectively. The area under study usually has its highest rainfall in July and lowest rainfall in December.

TABLE II: MEAN MONTHLY RAINFALL

\begin{tabular}{ccc}
\hline Months (2005-2015) & Monthly Total & Monthly Mean \\
\hline January & 406.9 & 36.9 \\
February & 931.0 & 84.6 \\
March & 1326.3 & 120.6 \\
April & 1938.5 & 176.2 \\
May & 3546.8 & 322.4 \\
June & 3680.1 & 334.6 \\
July & 4655.3 & 423.2 \\
August & 3487.1 & 317.0 \\
September & 4151.3 & 377.3 \\
October & 4046.4 & 367.8 \\
November & 1444.3 & 131.3 \\
December & 397.1 & 36.1 \\
\hline
\end{tabular}

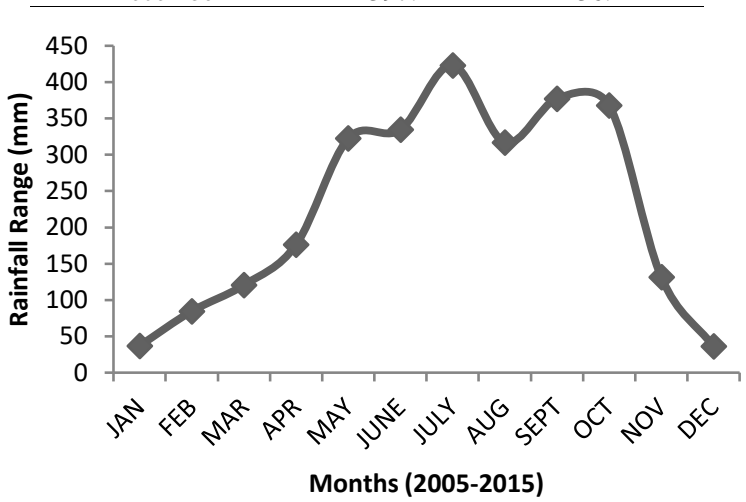

Fig. 5. Mean Monthly Rainfall Trend.

\section{Monthly Rainfall Percentage Contribution}

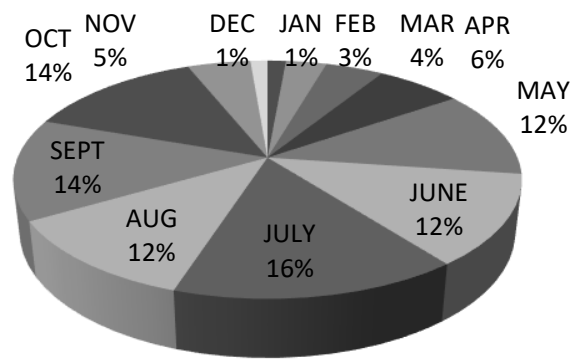

\section{Mean Monthly and Annual Temperature}

The mean monthly and annual temperature for the study area over a period of 11 years (2005-2015) is shown below on Fig. 7 and 8 and Table III.

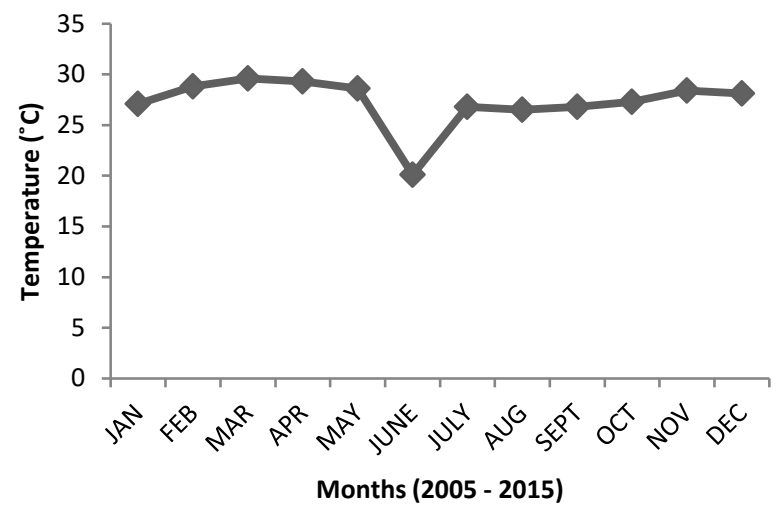

Fig. 7. Mean Monthly Temperature.

Fig. 7 reveals a steady trend of monthly total temperature in Warri, Delta State with the exception of June which experiences a significantly lower temperature compared to all other months.

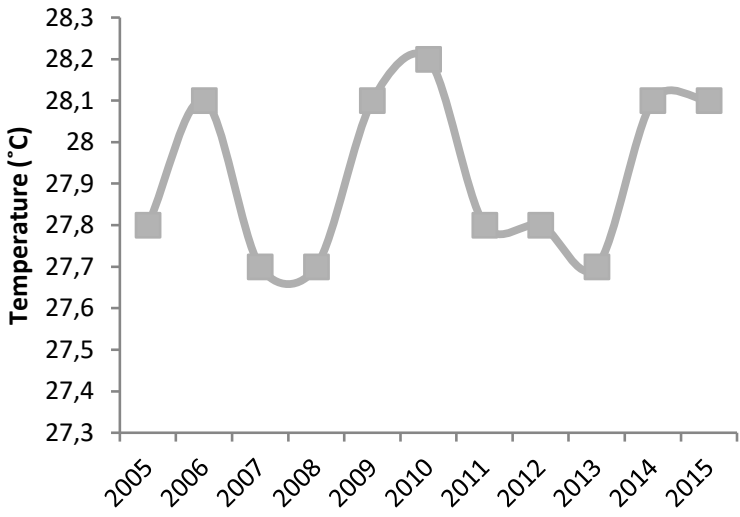

Fig. 8. Mean Annual Temperature.

Fig. 8 shows that highest mean annual temperature was recorded in 2010. It also indicates steady rise from 2014 and 2015 .

Fig. 6. Monthly contribution to the total of means annual rainfall. 
TABLE III: MONTHLy AVERAGE TEMPERATURE

\begin{tabular}{|c|c|c|c|c|c|c|c|c|c|c|c|c|c|}
\hline \multirow[b]{2}{*}{ Years } & \multicolumn{13}{|c|}{ MONTHS $\left({ }^{\circ} \mathrm{C}\right)$} \\
\hline & Jan & Feb & Mar & Apr & May & Jun & Jul & Aug & Sept & Oct & Nov & Dec & $\begin{array}{c}\text { Annual Total } \\
\text { Mean }\end{array}$ \\
\hline 2005 & 25.6 & 29.1 & 29.3 & 29.6 & 28.2 & 27.6 & 26.3 & 26.6 & 27.2 & 27.5 & 29.0 & 27.9 & 27.8 \\
\hline 2006 & 28.3 & 28.8 & 29.3 & 28.8 & 29.9 & 28.1 & 28.2 & 26.6 & 26.1 & 26.2 & 28.9 & 27.6 & 28.1 \\
\hline 2007 & 26.6 & 28.8 & 29.9 & 29.3 & 28.3 & N/A & 26.6 & 26.9 & 26.3 & 26.6 & 27.9 & 27.6 & 27.7 \\
\hline 2008 & 26.4 & 28.1 & 29.2 & 28.2 & 27.9 & 27.5 & 26.6 & 26.3 & 26.6 & 28.1 & 29.0 & 28.3 & 27.7 \\
\hline 2009 & 27.8 & 28.8 & 30.1 & 29.1 & 29.0 & 28.0 & 26.7 & 26.0 & 26.7 & 27.1 & 28.6 & 28.8 & 28.1 \\
\hline 2010 & 27.5 & 29.6 & 30.0 & 29.9 & 29.2 & 28.1 & 27.4 & 26.6 & 27.0 & 27.0 & 28.9 & 28.3 & 28.2 \\
\hline 2011 & 26.5 & 28.2 & 29.5 & 29.4 & 28.4 & 27.5 & 26.2 & 26.2 & 27.1 & 27.3 & 29.1 & 27.7 & 27.8 \\
\hline 2012 & 26.9 & 28.2 & 29.7 & 29.3 & 28.2 & 27.1 & 26.6 & 26.7 & 27.0 & 27.0 & 29.0 & 28.3 & 27.8 \\
\hline 2013 & 27.4 & 28.8 & 29.7 & 29.7 & 28.9 & 27.6 & 26.5 & 26.4 & 27.0 & 28.1 & 23.7 & 28.2 & 27.7 \\
\hline 2014 & 27.9 & 28.8 & 29.1 & 29.3 & 28.7 & 28.4 & 27.2 & 26.5 & 26.6 & 27.5 & 28.6 & 28.5 & 28.1 \\
\hline 2015 & 26.7 & 29.3 & 29.5 & 29.7 & 29.1 & 27.4 & 26.7 & 26.2 & 26.8 & 28.2 & 29.4 & 27.9 & 28.1 \\
\hline $\begin{array}{l}\text { Monthly Total } \\
\text { Mean }\end{array}$ & 27.1 & 28.8 & 29.6 & 29.3 & 28.7 & 27.7 & 26.8 & 26.5 & 26.8 & 27.3 & 28.4 & 28.1 & \\
\hline
\end{tabular}

E. Frequency and Cumulative Frequency of Mean Monthly Temperature

TABLE IV: FREQUENCY AND CUMULATIVE FREQUENCY OF MEAN

\begin{tabular}{ccc}
\multicolumn{3}{c}{ MONTHLY TEMPERATURE } \\
\hline Intervals & Frequency & Cumulative Frequency \\
\hline $23.7-24.4$ & 1 & 1 \\
$24.5-25.2$ & 0 & 1 \\
$25.3-26.0$ & 2 & 3 \\
$26.1-26.8$ & 29 & 32 \\
$26.9-27.6$ & 25 & 57 \\
$27.7-28.4$ & 28 & 85 \\
$28.5-29.2$ & 25 & 110 \\
$29.3-29.9$ & 19 & 129 \\
$30.0-30.7$ & 3 & 132 \\
\hline
\end{tabular}

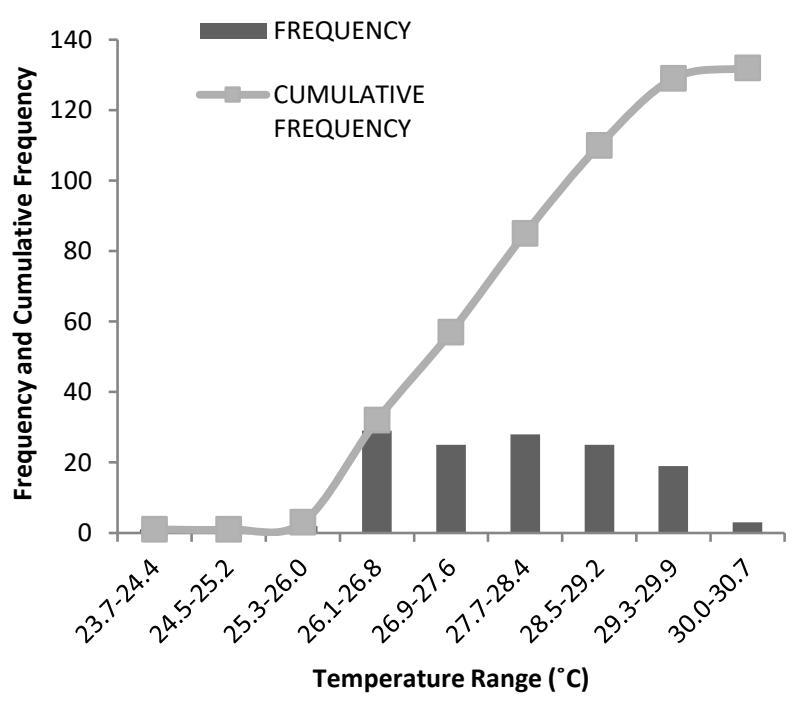

Fig. 9. Frequency and Cumulative Frequency of Mean Monthly Temperature.

From Fig. 9 most dominant temperature ranges between 26.1 and $26.8^{\circ} \mathrm{C}$ closely followed by $27.7-28.4^{\circ} \mathrm{C}$ which are quite close to the mean monthly values in the area.

\section{CONCLUSION}

Analysis of data provides evidence that there are fluctuations in the rainfall and temperature trend in the study area. Rainfall is at an increasing trend within the last two years of the period under investigation (2014 and 2015) while temperature also increased albeit slightly. Crops need water for optimum development but with the increasing volume of rainfall in the state (see Fig. 1) there is a danger of flood occurrence which could lead to crop failure thereby resulting in famine and/or food insecurity in the area if prompt action is not taken. A variety of crops such as maize, yam and cassava produced in the Niger Delta region depend on rainfall for their optimum performance and therefore are vulnerable. Consequently, livelihood and general wellbeing could be threatened. With respect to health implications, mosquitoborne diseases are probably the greatest threat to humans as they include malaria, elephantiasis, yellow fever etc. Studies are showing higher prevalence of these diseases in areas that have experienced extreme flooding. Flooding creates more standing water for mosquitoes to breed; as well, shown that these vectors are able to feed more and grow faster in wetter and warmer climates. The two variables - rainfall and temperature - should be constantly monitored to prevent occurrence of natural disaster such as flooding which could have a devastating effect on the people and biodiversity as plants and animals are known to be sensitive to fluctuations in temperature and moisture. This was demonstrated during the 2012 city wide flood episode.

\section{REFERENCES}

[1] A.A. Akinsanola and K.O. Ogunjobi (2014). "Analysis of Rainfall and Temperature Variability over Nigeria”. Global Journal of HumanSocial Science. 14(3), pp 34-42. https://globaljournals.org/GJHSS_Volume14/1-Analysis-of-Rainfalland-Temperature.pdf.

[2] Intergovernmental Panel on Climate (2007). "Climate change 2007: Synthesis report. Summary for policy makers". https://www.ipcc.ch/site/assets/uploads/2018/02/ar4-wg1-spm-1.pdf.

[3] F. Odemerho (2008). Map of Delta State, Nigeria showing Urhoboland and other Ethnic Nationalities. Urhobo Historical Sociesty. http://www.waado.org/nigerdelta/maps/delta_state/delta_state_ethnic. html.

[4] https://en.wikipedia.org/wiki/Warri.

[5] Nigerian Meteorological Agency (NIMET). Nigeria Climate Review. Abuja, Nigeria. http://nimet.gov.ng/seasonal-rainfallprediction-2014by-NiMet. 